\title{
Developmental regulation and partial characterization of growth factors in the bovine mammary gland
}

\author{
R. S. Talhouk ${ }^{1}$, R. L. Neiswander ${ }^{2}$ and F. L. Schanbacher ${ }^{2}$ \\ ${ }^{1}$ Biology Department, PO Box 11-0236, American University of Beirut, Beirut, Lebanon; and \\ ${ }^{2}$ Department of Animal Science, Laboratories of Molecular and Developmental Biology, Ohio Agricultural \\ Research and Development Center, Ohio State University, Wooster, OH 44691, USA
}

\begin{abstract}
Bovine mammary gland secretions from several developmental stages were shown to stimulate $\left[{ }^{3} \mathrm{H}\right]$ thymidine incorporation into AKR-2B mouse embryo fibroblast cells. In virgin heifers, mammary secretions at $1 \%$ concentration stimulated thymidine incorporation into AKR-2B cells more than threefold compared with $10 \%(\mathrm{v} / \mathrm{v})$ fetal calf serum. The growth-promoting activity peaked at an early stage of the last trimester (7-8 months) of gestation and declined after this until the colostrum forming stage. At this point, the activity was one- to twofold that induced by $10 \%(\mathrm{v} / \mathrm{v})$ fetal calf serum. At parturition the activity dropped abruptly to virtually undetectable values in milk. The developmental change in activity could be mimicked by hormonal priming of the mammary gland. The partial characterization of the growth promoting activities in secretions at the seventh month of gestation revealed at least two major growth-promoting activities: bovine mammary derived growth factor 1 (bMDGF-1), an epidermal growth factor-like growth factor with a molecular weight of 30000 , which is trypsin sensitive and heat stable, and bMDGF-2, which eluted under gel filtration conditions at a molecular weight of 50000 and 150000 . bMDGF- 1 is predominant in pregnant, precolostric, and colostric secretions, and is not detected in milk. bMDGF-2 is the major growth factor in milk. These results show developmental regulation and modulation of growth-promoting factors during the different stages of mammary gland development and suggest that growth factors are involved in regulating growth during gestation.
\end{abstract}

\section{Introduction}

Milk contains a variety of polypeptide growth factors (GF) that vary with the stage of lactation and species (Klagsbrun and Neumann, 1979; Sereni and Berserga, 1981; Read et al., 1984; Shing and Klagsbrun, 1984; Dembinski and Shiu, 1987; Forsyth, 1991; Plaut, 1993; Marcotty et al., 1994). A 30000 molecular weight platelet-derived growth factor (PDGF)-like activity was reported in goat, bovine and sheep colostrum (Brown and Blakeley, 1983a, b, 1984). Furthermore, insulin-like growth factor (IGF)-I, IGF-II and transforming growth factor $\beta 2$ (TGF- $\beta 2$ ) related growth factor have been identified in bovine milk and colostrum (Francis et al., 1986, 1988; Campbell and Baumrucker, 1989; Tokuyama and Tokuyama, 1993), while epidermal growth factor (EGF) and EGF-like activity (Carpenter, 1980; Shing and Klagsbrun, 1984), IGF-I and IGF-II (Baxter et al., 1984; Eriksson et al., 1993) were reported in human milk which is known to contain at least 14 growth factors (Kidwell and Salomon, 1987).

It has been widely presumed that growth factors in mammary secretions modulate the growth of neonatal systems (Schober ef al., 1990; Baumrucker and Blum, 1994). However,

Received 5 July 1995 support for the concept that these growth-promoting activities are involved in regulating growth of the mammary gland is beginning to emerge (Dembinski and Shiu, 1987; Oka et al., 1991; Plaut 1993; Brem et al., 1994; Pollard and Henninghausen, 1994; Soriano et al, 1995). For this to be the case, growth factors would have to be detected not only in precolostric secretions (Skaar et al., 1991) but also in mammary secretions when maximal growth of the gland is known to occur. Fenton and Sheffield (1991) showed that expression of mRNA encoding EGF in mouse mammary gland is under the control of lactogenic hormones. Furthermore, Spitzer and Grosse (1987) identified EGF receptors in bovine mammary plasma membranes at different stages of mammary development and lactation, and reported the highest concentrations of receptors on the plasma membrane of pregnant animals.

Studies that describe modulation of growth factors at the different stages of mammary gland development (virgin, gestation, parturition and lactation) are few. We report here developmental regulation of growth-promoting activities in secretions from virgin, gestating, and lactating bovine mammary gland. The partial purification and characterization of the growth factors in mammary secretions from animals at midpregnancy, a period when growth-promoting activity is at its peak, is also described. 


\section{Materials and Methods}

\section{Materials}

Tissue culture media were from M.A. Bioproducts (Walkersville, MD). Cell culture plates were purchased from Bellco (Vineland, NJ). The AKR-2B cell line was a generous gift from H. L. Moses (Vanderbilt University, TN). Receptor grade mouse epidermal growth factor (mEGF) was from Collaborative Research (Bedford, MA). ${ }^{125}$ I-labelled mEGF receptor grade $\left(107 \mu \mathrm{Ci} \mu \mathrm{g}^{-1}\right.$ ) and methyl- $\left[{ }^{3} \mathrm{H}\right]$ thymidine $(32 \mathrm{Ci}$ $\mathrm{mmol}^{-1}$ ) were obtained from ICN Biochemicals (Irvine, CA) and New England Nuclear (Boston, MA), respectively. Liquid chromatography gels (DEAE-Sepharose CL-6B, CM-Sepharose $\mathrm{CL}-6 \mathrm{~B}$, and Sephacryl S200 superfine) were from Sigma Chemical Company (St Louis, MO).

\section{Collection of mammary secretions}

Mammary secretions were collected by manual expression from either primiparous adult dairy cattle at different stages of mammary development, or from nulligravida dairy heifers at selected stages during hormonally induced bovine mammary development (Smith and Schanbacher, 1973). Mature milk was obtained fresh from the refrigerated bulk tank at the Ohio Agriculture Research and Development Center (OARDC) dairy research facility. All milk and mammary secretion samples were kept on ice. Cell debris and fat were removed by centrifugation at $30000 \mathrm{~g}$ for $30 \mathrm{~min}$ at $4^{\circ} \mathrm{C}$. The supernatant fat layer and the debris pellet were discarded; the recovered subnatant (mammary secretion or milk) was decaseinated by acidification to $\mathrm{pH} 4.5$ with acetic acid and centrifuged at $30000 \mathrm{~g}$ for $30 \mathrm{~min}$ at $4^{\circ} \mathrm{C}$ to remove precipitated casein. The supernatant whey preparation was then dialysed (molecular weight size exclusion at 14000 ) overnight against $0.01 \mathrm{~mol}$ $\mathrm{NaAc} 1^{-1}, \mathrm{pH} 5.6$, or adjusted to $\mathrm{pH} 5.6$ with $\mathrm{NaOH}$, and then either loaded onto an ion exchange chromatography column, or stored at $-20^{\circ} \mathrm{C}$ until further use. The defatted, decaseinated, and dialysed mammary secretion is referred to as 'decaseinated secretion' hereafter.

\section{Cell cultures}

Mitogenic activity was measured by stimulation of $\left[{ }^{3} \mathrm{H}\right]$ thymidine incorporation in target cell lines. For routine mitogenic activity assays, AKR-2B mouse embryo fibroblast cells were used. Human A431 epidermoid cells (American Type Culture Collection, Rockville, $\mathrm{MD}$ ), and $\mathrm{BALB} / \mathrm{c} 3 \mathrm{~T} 3$ cells from the $\mathrm{NIH}$ (Bethesda, MD) were also used for selected receptor or mitogenesis studies. Cells were grown in Dulbecco's modified Eagle's medium (DMEM), supplemented with $10 \%(\mathrm{v} / \mathrm{v})$ fetal calf serum (FCS) and gentamycin $\left(50 \mu \mathrm{g} \mathrm{ml}^{-1}\right)$ in a humidified incubator $\left(95 \%\right.$ air: $\left.5 \% \mathrm{CO}_{2}\right)$ at $37^{\circ} \mathrm{C}$.

Decaseinated secretions from a primagravida heifer at 7 months of gestation were tested for their ability to stimulate $\left[{ }^{3} \mathrm{H}\right]$ thymidine incorporation into different cell lines. The cell lines used (mouse 3T3, and AKR-2B, as well as human A431) showed varied responses to the addition of the mammary secretions. The majority of $\mathrm{BALB} / \mathrm{C} 3 \mathrm{~T} 3$ cell monolayers detached upon the addition of the decaseinated mammary secretions even at very low concentrations, while A431 cells showed a low amount of $\left[{ }^{3} \mathrm{H}\right]$ thymidine incorporation upon stimulation. The AKR-2B cells responded with a high amount of $\left[{ }^{3} \mathrm{H}\right]$ thymidine incorporation and, henceforth, this cell line was used throughout these studies.

\section{Mitogen assay}

The $\left[{ }^{3} \mathrm{H}\right]$ thymidine incorporation assay was a modification of procedures described by Brown and Blakeley (1984), Klagsbrun (1978), and Simmen et al. (1988). AKR-2B cells were subcultured into 24-well plates by seeding at $1 \times 10^{5} \mathrm{cells}^{-1}$ per well in $1.0 \mathrm{ml}$ DMEM supplemented with $10 \%(\mathrm{v} / \mathrm{v}) \mathrm{FCS}$, until growth to confluent monolayers (usually by $72 \mathrm{~h}$ ). Upon confluence, cells were changed to serum-deficient medium (DMEM with $2 \%(\mathrm{v} / \mathrm{v})$ FCS) and incubated for $48 \mathrm{~h}$ to stop proliferation by serum depletion and density-dependent arrest before application of mitogen preparation. For assessing GF activity, decaseinated secretion, or fractions from column chromatography, was added to arrested cells after dilution to the concentration desired. The final volume of the test solution was adjusted to $100 \mu \mathrm{l}$ per well with sterile Hank's balanced salt solution (HBSS). After $20 \mathrm{~h}$ at $37^{\circ} \mathrm{C}$, when maximal DNA synthesis is achieved, $\left[{ }^{3} \mathrm{H}\right]$ thymidine ( $\mathrm{I} \mu \mathrm{Ci}$ per well, diluted to $50 \mu \mathrm{l}$ with HBSS) was added to each well, and incubation continued for another $4 \mathrm{~h}$ at $37^{\circ} \mathrm{C}$. The cells were then washed with $1 \mathrm{ml}$ PBS (15 mmol $\mathrm{HPO}_{4} \mathrm{I}^{-1}, 0.85 \%$ (w/v) $\mathrm{NaCl}$; $\mathrm{pH}$ 7.2), washed twice with $1 \mathrm{ml}$ methanol per well $(5 \mathrm{~min})$, then four times with $1 \mathrm{ml}$ water per well. Cellular proteins were precipitated in situ by two $5 \mathrm{~min}$ washes with cold $5 \%(\mathrm{w} / \mathrm{v})$ trichloroacetic acid $(1 \mathrm{ml}$ each), and then solubilized with $300 \mu \mathrm{l}$ of $0.3 \mathrm{~mol} \mathrm{NaOH} \mathrm{l}{ }^{-1}$, and transferred to liquid scintillation vials for liquid scintillation counting (Ecolume; ICN, Irvine, $\mathrm{CA}$ ).

\section{Liquid chromatography}

Anion (DEAE-Sepharose CL-6B) or cation (CM-Sepharose CL-6B) exchange chromatography was performed on columns equilibrated at $4^{\circ} \mathrm{C}$ in 0.01 mol NaAc $1^{-1}, \mathrm{pH}$ 5.6. The decaseinated secretions were loaded onto the column. Seventy-

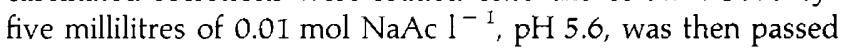
through the column before an $800 \mathrm{ml} \mathrm{NaCl}$ gradient $(0-2 \mathrm{~mol}$ $\left.1^{-1}\right)$ was started to elute bound proteins. Fractions were collected, and the protein elution profile determined at $280 \mathrm{~nm}$, while growth-promoting activity was determined by addition of aliquots to AKR-2B cells for mitogenesis assays as described.

For further purification and determination of the apparent molecular weight of the mitogenic activity, peaks of growthpromoting activity were pooled and concentrated by precipitation with $80 \%(\mathrm{v} / \mathrm{v})$ saturated ammonium sulfate. The precipitate was dissolved in a minimal volume of PBS, pH 7.2, dialysed overnight against PBS, pH 7.2, and loaded onto a Sephacryl S200 column $(2.6 \mathrm{~cm} \times 85 \mathrm{~cm})$ equilibrated with PBS at $4^{\circ} \mathrm{C}, \mathrm{pH}$ 7.2. Column fractions were analysed for total proteins and for growth-promoting activity. Specific milk proteins, as internal markers in column fractions, were determined with biotin-avidin-horseradish peroxidase ELISA using 
biotinylated antibody monospecific for bovine immunoglobulins, bovine lactoferrin, bovine serum albumin, $\beta$-lactoglobulin and a-lactalbumin (Talhouk et al., 1990).

\section{Radioreceptor competitive binding assay}

The radioreceptor competitive binding assay for ${ }^{125}$ I-labelled mEGF used was a modification of that described by Carpenter et al. (1975) and Brown and Blakeley (1983b). Confluent serum arrested AKR-2B cells were washed twice with $1 \mathrm{ml}$ binding buffer $10.1 \%(\mathrm{w} / \mathrm{v}) \mathrm{BSA}$, and $5 \mathrm{mmol} \mathrm{MgCl}_{2} \mathrm{I}^{-1}$ in PBS; $\mathrm{pH}$ 7.4). Decaseinated secretions, or void volume fractions from a DEAE-Sepharose column were diluted to the desired concentration in binding buffer. The treatment in a total of $0.5 \mathrm{ml}$ in binding buffer containing $1 \mathrm{ng} \mathrm{ml}{ }^{-1}$ of ${ }^{125}$-labelled mEGF (200 000 c.p.m. $\mathrm{ng}^{-1}$; specific activity $107-144 \mu \mathrm{Ci}$ $\mu \mathrm{g}^{-1}$ ) was added per well and incubated at $37^{\circ} \mathrm{C}$ and $4^{\circ} \mathrm{C}$ for $90 \mathrm{~min}$. The cells were then washed twice with $0.5 \mathrm{ml}$ cold binding buffer to remove unbound ligand, solubilized in $0.5 \mathrm{ml}$ of $0.3 \mathrm{~mol} \mathrm{NaOH} \mathrm{^{-1 }}$ for $10-20 \mathrm{~min}$, at $37^{\circ} \mathrm{C}$, and the solubilized well contents were transferred to polystyrene tubes for gamma counting (Isodyne, model 1185) to determine the ${ }^{125}$ I-labelled mEGF bound.

For confirmation of binding, a standard competitive binding assay was performed on AKR-2B cells with mEGF, at concentrations ranging from 0 to $20 \mathrm{ng} \mathrm{ml}^{-1}$, and nonspecific binding was determined in the presence of $2 \mu \mathrm{g}$ unlabelled $\mathrm{mEGF} \mathrm{ml}^{-1}$. All binding assay samples were run in triplicate.

\section{Physical and chemical characterization}

Partially purified mammary growth-promoting activity was subjected to proteolysis with both trypsin-chymotrypsin $\left(0.5 \mathrm{mg} \mathrm{ml}{ }^{-1}\right)$ for $4 \mathrm{~h}$ at $37^{\circ} \mathrm{C}$, and then the addition of soybean trypsin inhibitor (STI, $2 \mathrm{mg} \mathrm{ml}^{-1}$ ) to inactivate the proteases and thereby allow assay for the mitogenic activity. The control consisted of the same concentration of mammary secretion and proteolytic enzymes incubated under the same conditions as above except that STI, used to inactivate the proteases, was added at the beginning of the incubation period. Separate assays showed that the proteolysis was completely

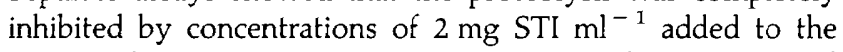
trypsin-chymotrypsin mixture. Sensitivity to heat was tested by subjecting bMDGF-I to $100^{\circ} \mathrm{C}$ for $5 \mathrm{~min}$, and the control was maintained on ice for the same period. Results are expressed as the ratio of $\left[{ }^{3} \mathrm{H}\right]$ thymidine incorporation induced in AKR-2B cells by the treated growth promoting activity to that of its control (untreated). Each sample was tested in triplicate.

\section{Results}

\section{Growth factor activity at different stages of mammary development}

Decaseinated mammary secretions from the later stages of pregnancy (7-8 months), when maximal gland growth is known to occur, induced $\left[{ }^{3} \mathrm{H}\right]$ thymidine incorporation into
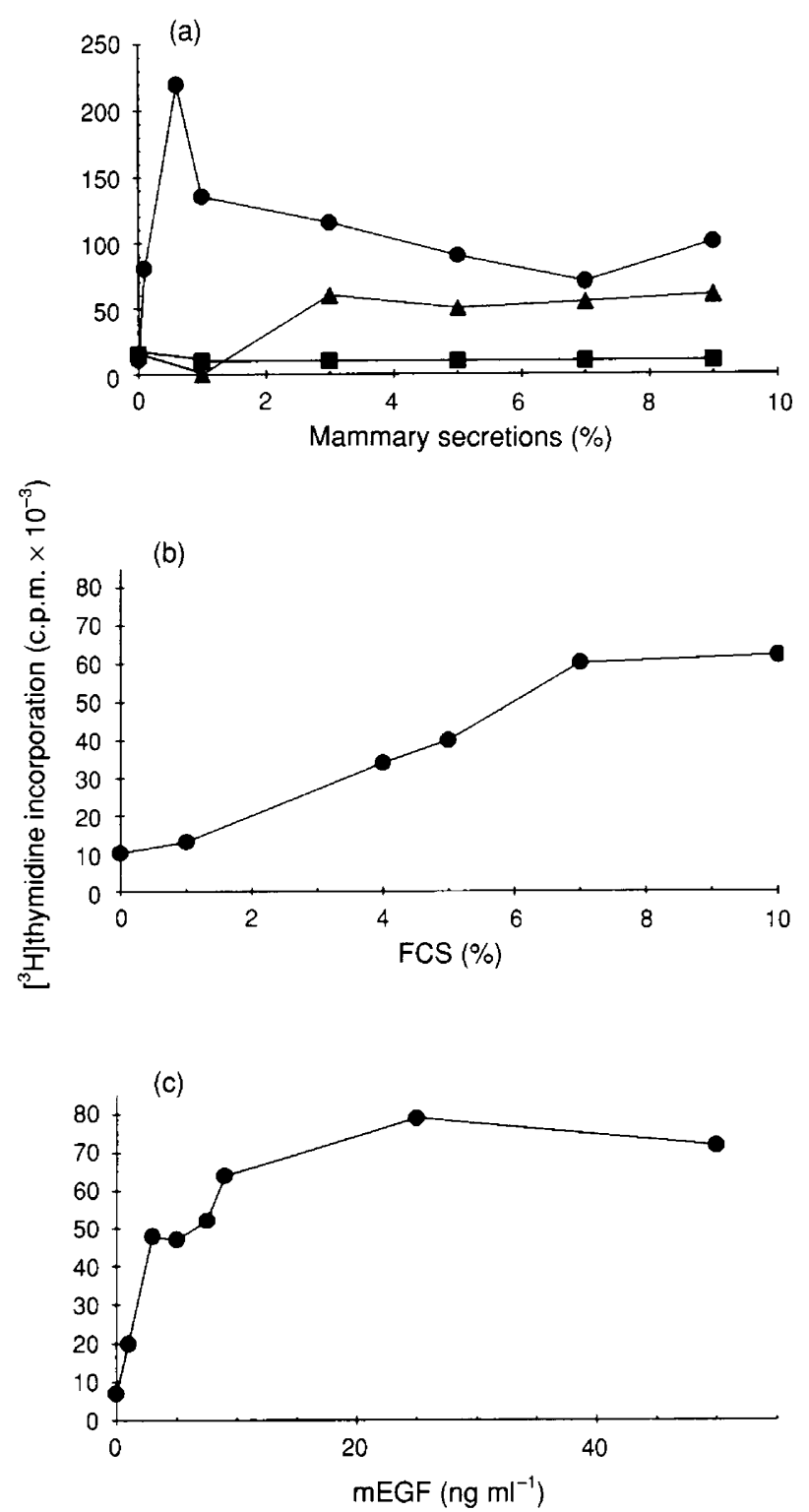

Fig. 1. Effect of skimmed mammary secretions, fetal calf serum (FCS), and epidermal growth factor (mEGF) on $\left[{ }^{3} \mathrm{H}\right]$ thymidine incorporation into AKR-2B cells. (a) Dose-response curves for increasing concentrations of decaseinated mammary secretions from $(\bullet)$ primagravida heifer at 7 month gestation, (4) colostrum forming stage and ( $\boldsymbol{\square}$ ) lactating state. Saturation profiles of (b) FCS and (c) mEGF. All samples were assayed in triplicate.

AKR-2B cells. To compare the growth-promoting activity in mammary secretions at this stage to growth-promoting activities in colostrum, milk, serum and EGF, we analysed the dose-response profiles of $\left.{ }^{3} \mathrm{H}\right]$ thymidine incorporation when AKR-2B cells were stimulated by the above. Maximum activity was achieved by the mammary gland secretions at a concentration of $0.5-1.5 \%(\mathrm{v} / \mathrm{v})$, and then declined at higher concentrations (Fig. 1a). This decline in $\left[{ }^{3} \mathrm{H}\right]$ thymidine incorporation was not due to cell death, since the cells failed to take up trypan blue, and they retained their ability to resume cell proliferation after exposure to $10 \%(\mathrm{v} / \mathrm{v})$ FCS (results not shown). The mitogenic activity was at least three- to fourfold 


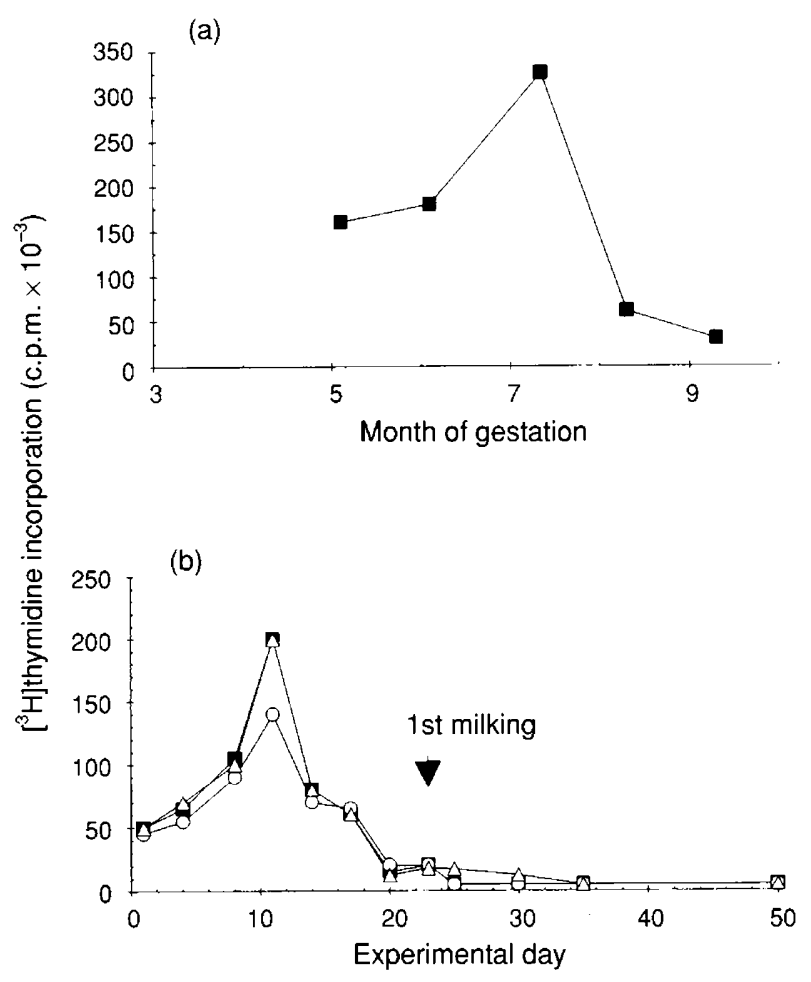

Fig. 2. The mitogenic activity of decaseinated mammary secretions assayed at $1 \%(\mathrm{v} / \mathrm{v})$ concentration taken at different stages of bovine mammary gland development. The mitogenic activity is determined as the ability of the secretion to stimulate $\left[{ }^{3} \mathrm{H}\right]$ thymidine incorporation into AKR-2B cells. (a) Samples from primagravida heifers, at different intervals during gestation. (b) Mammary secretions from three different nulligravida heifers, induced into mammary development by oestrogen/progesterone injection according to Smith and Schanbacher (1973).

that of the highest noted for colostrum (Fig. 1a), FCS (Fig. 1b) and mEGF (Fig. Ic). Colostrum, FCS, or mEGF did not show any evidence of inhibition of growth-promoting activity at high concentrations. No significant stimulation of $\left[{ }^{3} \mathrm{H}\right]$ thymidine incorporation was induced by bovine milk (Fig. Ia).

The mitogenic activity in decaseinated secretions from 7-8 month primagravida heifers was severalfold that of colostrum and milk, and this suggests that activity was modulated at the different stages of pregnancy and mammary development. Mitogenic activity peaked during the latter part of pregnancy (approximately at 7 months, Fig. 2a; or day $11-14$ in a hormonally induced developing gland, Fig. $2 b$ ) and then declined until the colostrum forming stage, after which the activity decreased to virtually undetectable amounts in milk. A mitogenic activity severalfold that found in colostrum or FCS at the same concentration of $1 \%(\mathrm{v} / \mathrm{v})$ (Fig. 1) was noted in mammary secretions of nonpregnant heifers.

\section{Fractionation of growth factors in mammary secretions}

The growth-promoting activities in the secretions obtained at 7 months of gestation were characterized by fractionating mammary secretions by ion exchange chromatography. At least two different growth-promoting activities were observed
(Fig. 3) and are designated here as "bovine mammary derived growth factor 1 and 2' (bMDGF-I and bMDGF-2). The former was retained on CM-Sepharose and was eluted at about $0.65 \mathrm{~mol} \mathrm{NaCl} \mathrm{l}^{-1}$ (Fig. 3a), but was in the void volume of the DEAE-Sepharose, and from this has a $\mathrm{pI}$ of $>8.6$, since it remained in the void volume portion when run on a DEAESepharose column, pH 8.6 (data not shown). The second growth-promoting activity, bMDGF-2, was retained on DEAESepharose and eluted at $0.3 \mathrm{~mol} \mathrm{NaCl} 1^{-1}$ (Fig. 3b), but was not retained on CM-Sepharose at $\mathrm{pH}$ 5.6. Typically, bMDGF-I stimulated $\left[{ }^{3} \mathrm{H}\right]$ thymidine uptake by AKR-2B cells three- to fourfold greater than that stimulated by bMDGF-2, under the same conditions. However, in a few samples the two activities were almost equal, but stimulation by bMDGF-2 was never greater than that by bMDGF-1.

The apparent molecular weights of bMDGF-1 and bMDGF-2 were determined by fractionating the dialysed and concentrated preparation of each on Sephacryl-S200 gel filtration columns. The activity of bMDGF- 1 eluted at a peak that corresponded to approximately 30000 molecular weight (Fig. $4 a)$, while the apparent molecular weight noted for bMDGF-2 was found in peaks with growth-promoting activity at 50000 and 150000 (Fig. 4b).

\section{Displacement of ${ }^{125}$ I-labelled $m E G F$ binding by bMDGF-1}

Since EGF and EGF-like activities were detected in colostrum and milk, and modulate mammary growth and development (Carpenter, 1980; Brown and Blakeley, 1983a; Plaut, 1993; Yang et al., 1995), tests were run to determine whether the growth-promoting activity in bovine mammary secretions of 7 month primagravida heifers was due to an EGF or EGF-like activity.

Decaseinated mammary secretions from a 7 month primagravida heifer (Fig. 5a), and partially purified bMDGF-1 eluted from DEAE-Sepharose (Fig. $5 \mathrm{~b}$ ), competed with ${ }^{125}$ I-labelled mEGF in a dose-dependent manner at $4^{\circ} \mathrm{C}$ and $37^{\circ} \mathrm{C}$. The ${ }_{125}$ I-labelled mEGF displacement at both temperatures was not total, and represented only $60 \%$ inhibition. However, purified receptor grade mEGF showed $80-90 \%$ inhibition at both temperatures (Fig. 5c).

\section{Physical and chemical characterization}

The effects of trypsin-chymotrypsin, heat treatment, $\mathrm{pH}$ and storage on the stability of the mitogenic activity of bMDGF-1 were determined. bMDGF-I was completely inactivated by the proteolytic enzymes. After heat treatment, only $18 \%$ inactivation of the growth factor ability to stimulate $\left[{ }^{3} \mathrm{H}\right]$ thymidine incorporation was noted, showing high stability to $100^{\circ} \mathrm{C}$ heat treatment. The ability of bMDGF- 1 and bMDGF- 2 to stimulate $\left[{ }^{3} \mathrm{H}\right]$ thymidine uptake in AKR-2B cells persisted after subjection to $\mathrm{pH}$ ranging from 4.5 to 8.6 .

The mitogenic activity in the decaseinated secretions before fractionation on column chromatography was not stable. Storage as decaseinated secretions for more than 2 weeks at $-20^{\circ} \mathrm{C}$ caused significant loss of bMDGF- 1 and bMDGF-2 activity. The growth-promoting activity was also lost after repeated freezing and thawing. However, partially 


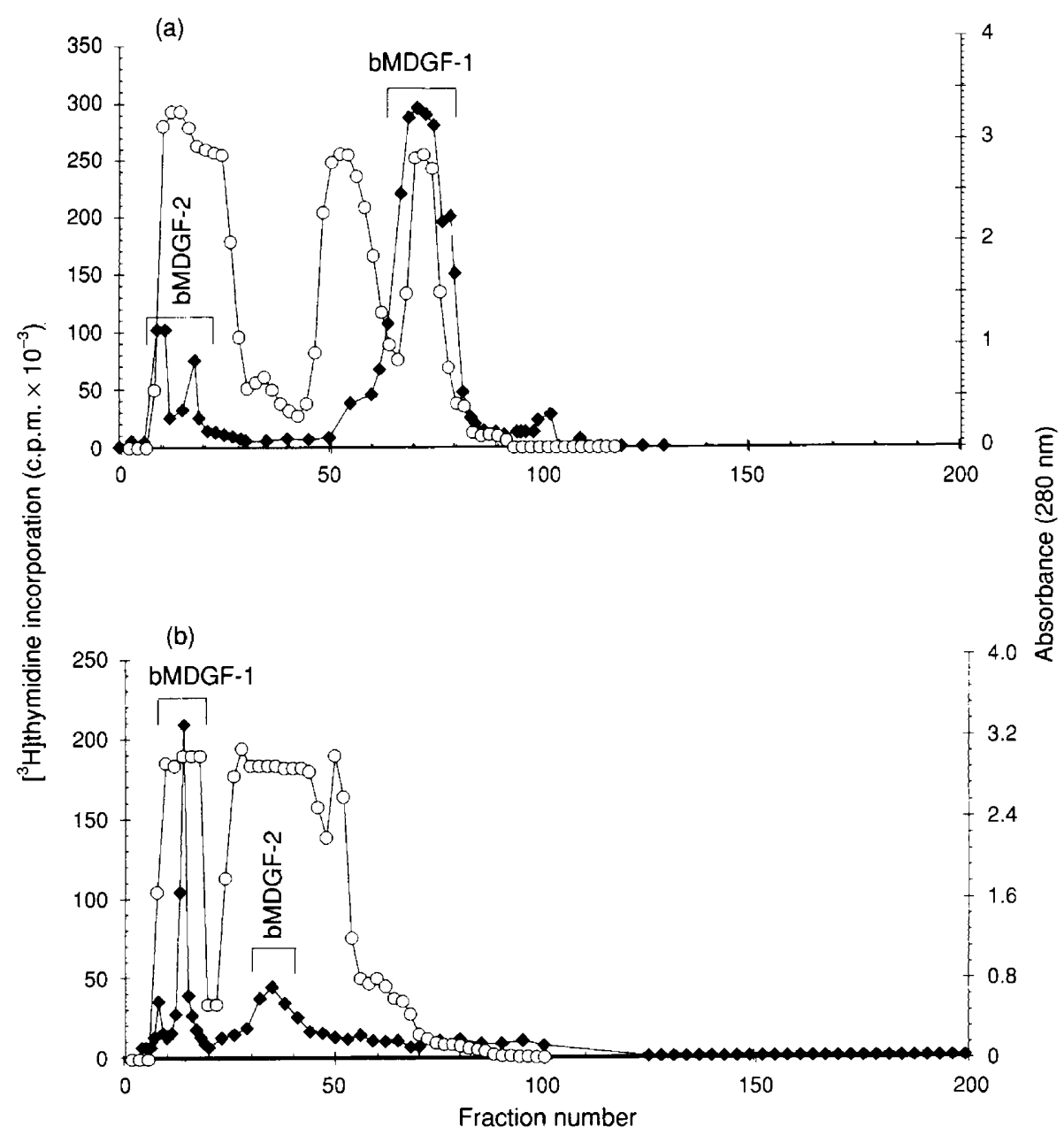

Fig. 3. Ion-exchange chromatography of decaseinated mammary secretions from a 7 months primagravida heifer were loaded onto (a) a CM-Sepharose column or (b) a DEAE-Sepharose column, pre-equilibrated in $0.01 \mathrm{~mol} \mathrm{NaAc} \mathrm{l}^{-1}, \mathrm{pH} 5.6,0-2 \mathrm{~mol} \mathrm{NaCl} \mathrm{l}^{-1}$ gradient. Purification was monitored by ability of $100 \mu \mathrm{l}$ aliquots of fractions eluted from the columns to stimulate $\left[{ }^{3} \mathrm{H}\right]$ thymidine incorporation into AKR-2B cells. Fractions were monitored for protein content by absorbance at $280 \mathrm{~nm}(\circlearrowleft)$ and assayed for mitogenic activity (•), in triplicate.

purified forms of bMDGF-1 and bMDGF-2 eluted from both ion exchange columns and size exclusion columns were stable for at least 3 months at $-20^{\circ} \mathrm{C}$, and after multiple freezings and thawings.

\section{Growth factor profiles in bovine colostrum and milk}

To determine whether the downregulation of growthpromoting activity noted in colostrum and milk is due to different factors, or is due to the modulation or absence of bMDGF-1 or bMDGF-2 from the latter two secretions, we compared the elution profile of growth-promoting activity in colostrum and milk with that of bMDGF- 1 and bMDGF-2. The $A_{280}$ and $\left[{ }^{3} \mathrm{H}\right]$ thymidine incorporation patterns of a decaseinated preparation from colostrum, and bovine milk after elution from a CM-Sepharose, $\mathrm{pH} 5.6$, with $0-2 \mathrm{~mol} \mathrm{NaCl} \mathrm{l}^{-1}$ gradient are shown (Fig. 6). The peaks of growth-promoting activity in colostrum (Fig. 6a) and milk (Fig. 6b), although lower in activity than mammary secretions from a 7 month prima- gravida heifer (compare with Fig. 3), eluted at similar $\mathrm{NaCl}$ concentrations to the growth factor in the mammary secretions of a primagravida heifer. In contrast to secretions from 7 month primagravida heifers, and colostrum, the activity of bMDGF-1 in milk was almost nondetectable and lower than that of bMDGF-2 (Fig. 6b). This finding suggests that bMDGF- 1 and bMDGF -2 are modulated and may be involved in regulating mammary gland growth and development. In addition, the results demonstrated that bMDGF- 1 and bMDGF- 2 are the major growth-promoting activities in colostrum and milk.

\section{Discussion}

In this study we report the presence of growth-promoting activity in mammary secretions from a nulligravida and from a mid-late gestating mammary gland of primagravida dairy cattle. The growth-promoting activity was regulated by the stage of gestation and peaked at the seventh month (or at day 
(a)

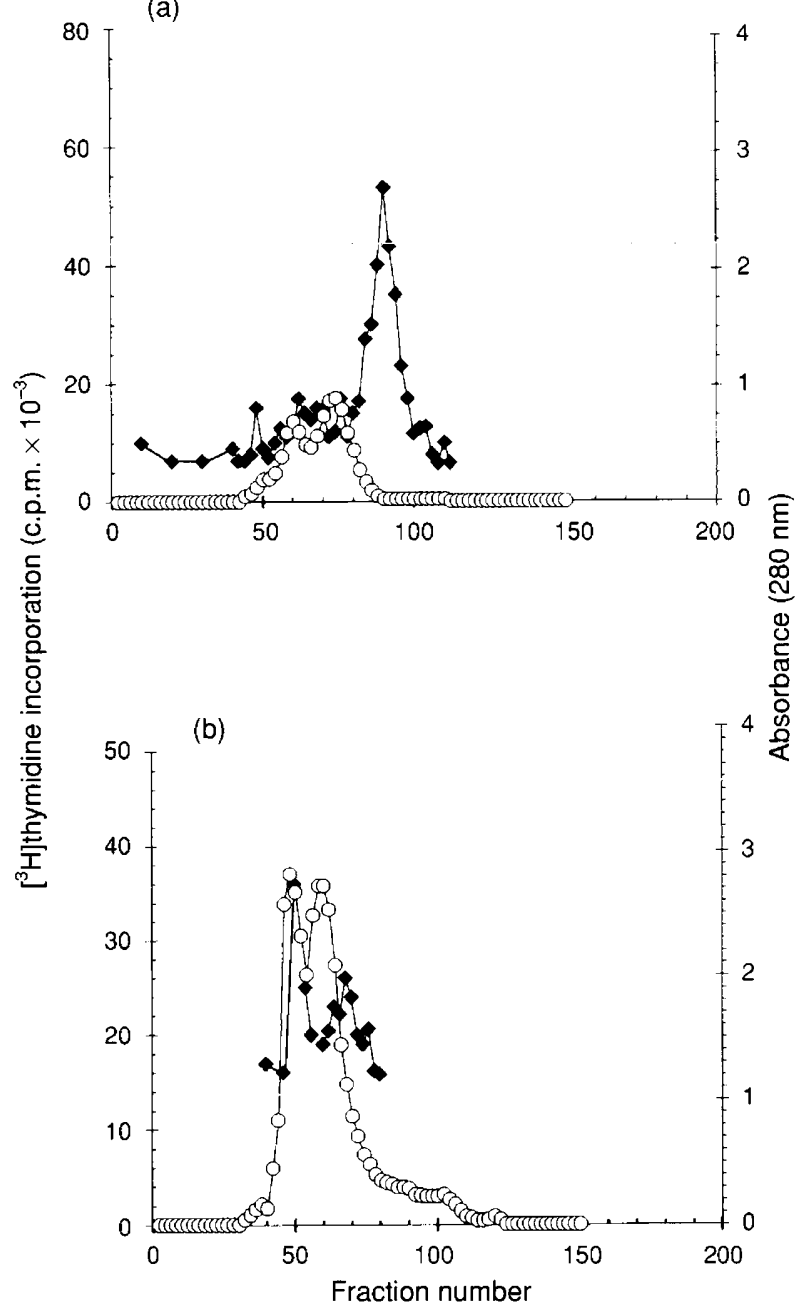

Fig. 4. Gel-filtration chromatography of pooled fractions containing growth-promoting activity (bMDGF-1 and bMDGF-2) eluting from CM-Sepharose. Fractions containing bMDGF-I and bMDGF-2 were pooled separately, concentrated and resuspended in minimal volume of PBS, pH 7.2 and loaded on a gel filtration column (S-200 Sephacryl) pre-equilibrated in PBS, pH 7.2, for determination of their apparent molecular weight. Apparent molecular weight of (a) bMDGF-I and (b) bMDGF-2 as monitored by the ability of fractions to stimulate $\left[{ }^{3} \mathrm{H}\right]$ thymidine incorporation into AKR-2B cells. Fractions were monitored by absorbance at $280 \mathrm{~nm}(0)$, and their ability to stimulate $\left[{ }^{3} \mathrm{H}\right]$ thymidine incorporation ( $\bullet$. Each value is a mean of three samples.

11-14 of a hormonally induced developing mammary gland). At this stage of gestation, the growth activity was severalfold that in colostrum. Two major growth factors were identified: an EFG-like bMDGF1, 30000 molecular weight, heat-resistant basic ( $\mathrm{pI}>8.6$ ) polypeptide, and bMDGF2, which was found in 50000 and 150000 apparent molecular weight complexes.

In contrast to the abundant literature describing growth factors in colostrum and milk (Kidwell and Salomon, 1987; Beardmore and Richards, 1983; Byyny et al., 1974; Brown and Blakeley, 1983a, 1984; Francis et al., 1986; Campbell and Baumrucker, 1989; Tokuyama and Tokuyama, 1993), few reports describe the temporal pattern of growth factor activity in mammary secretions across mammary development (Skaar
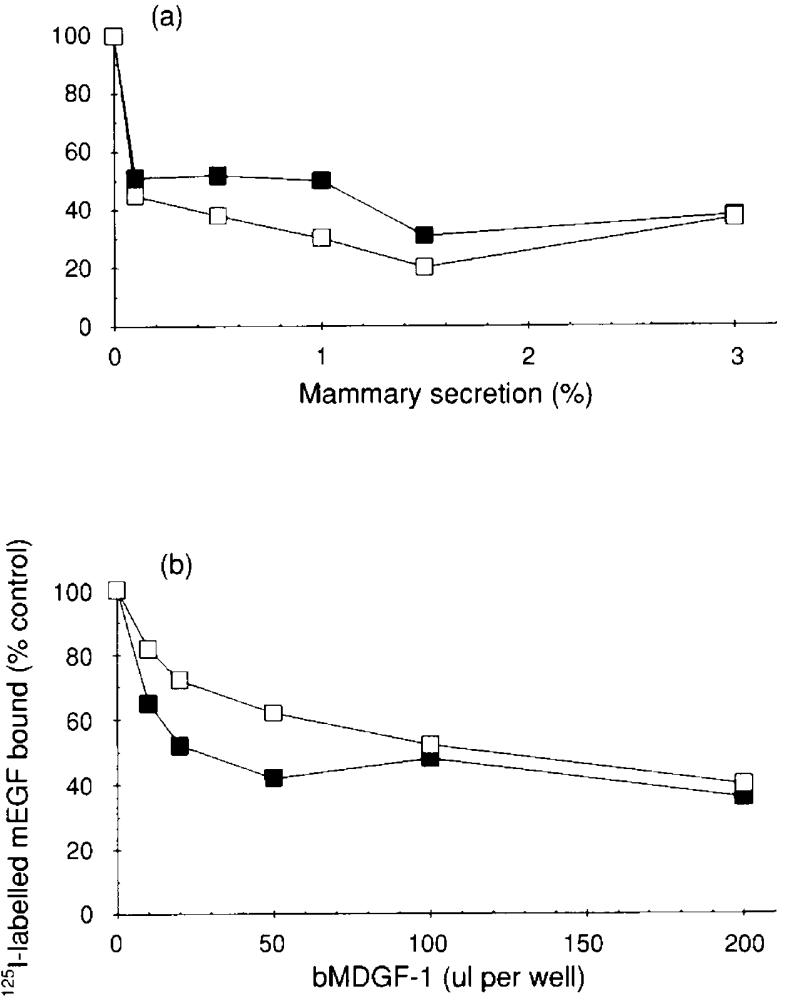

(c)

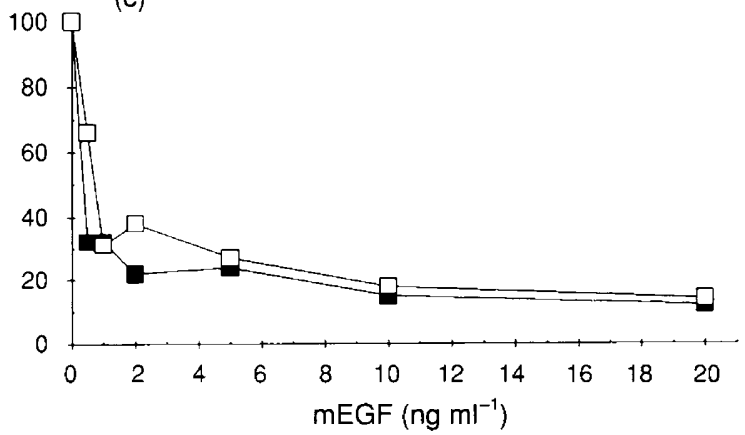

Fig. 5. Inhibition of ${ }^{125}$ I-labelled mEGF binding to AKR-2B cells by (a) skimmed mammary secretions from a 7 month primagravida heifer, (b) partially purified bMDGF-1 (from DEAE ion exchange chromatography; Fig. 3b), and (c) receptor grade mEGF, at $37^{\circ} \mathrm{C}(\square)$ and $4^{\circ} \mathrm{C}$ ( Each point represents the mean value of three samples, expressed as percentage of ${ }^{125} \mathrm{I}$-labelled $\mathrm{mEGF}$ bound to untreated cells.

et al., 1991; Winder et al., 1993; Marcotty et al., 1994). While growth of the mammary gland occurs throughout gestation, aggressive growth occurs during the latter part of gestation (Cowie, 1971) under hormonal control; and evidence from in vivo and culture studies suggests the involvement of growth factors (reviewed by Forsyth, 1991; Oka et al., 1991; Plaut, 1993; Pollard and Henninghausen, 1994; Spitzer et al., 1995).

Mammary gland secretions induced $\left[{ }^{3} \mathrm{H}\right]$ thymidine incorporation into AKR-2B cells to extents that varied with the developmental stage of the gland, and the type and abundance of growth factors detected at the different developmental 


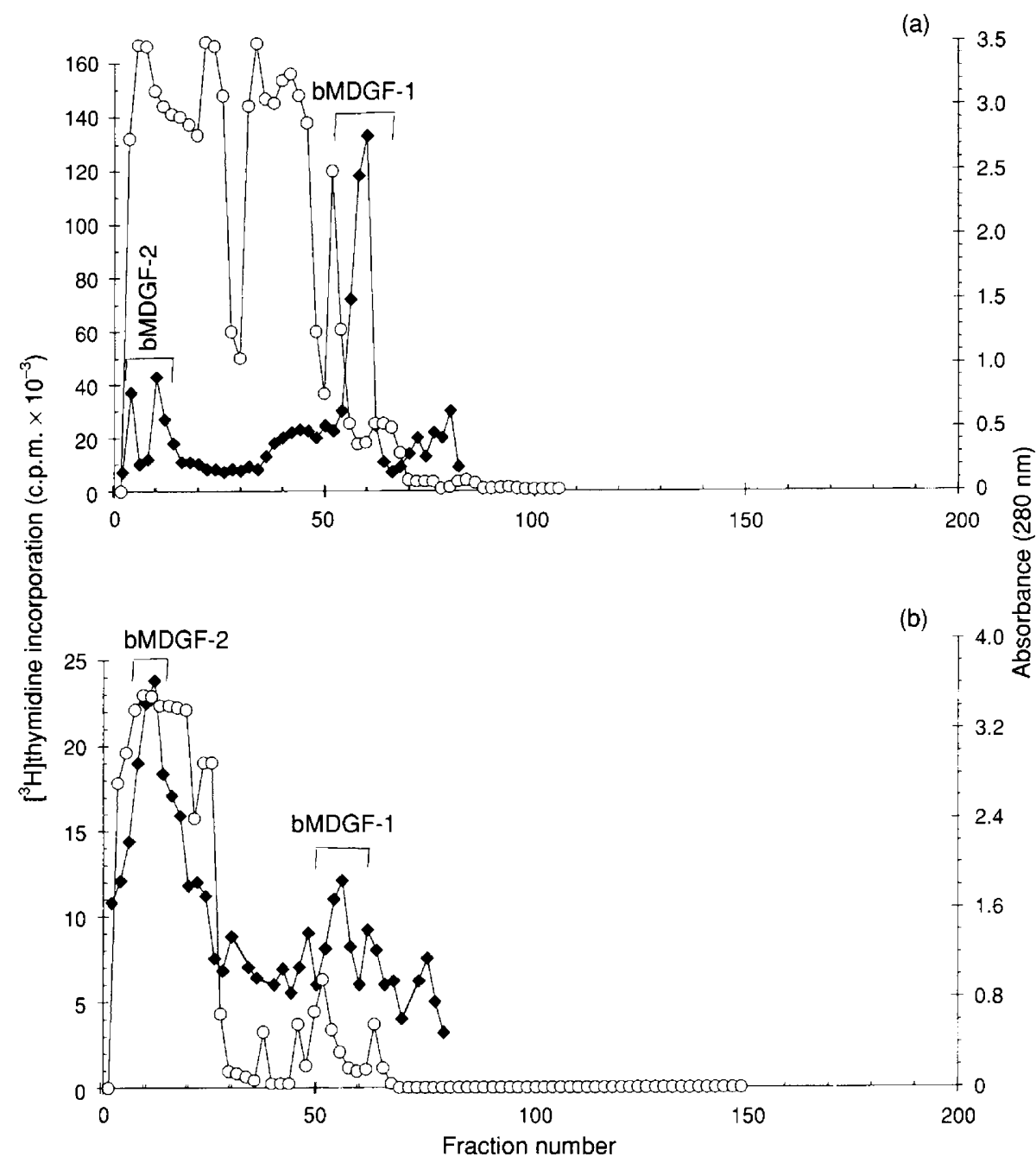

Fig. 6. CM-Sepharose cation exchange chromatography of decaseinated mammary secretions from (a) colostrum of a primagravida heifer obtained at parturition, and (b) milk obtained from the bulk tank container. These were loaded onto a CM-Sepharose column, pre-equilibrated in $0.01 \mathrm{~mol}$ $\mathrm{NaAcl}^{-1}, \mathrm{pH}$ 5.6. The fractions were monitored for total protein absorbance at $280 \mathrm{~nm}(\mathrm{)})$, and their ability to stimulate $\left[{ }^{3} \mathrm{H}\right]$ thymidine incorporation into AKR-2B cells $(\bullet)$. Equal amounts of protein from decaseinated secretions (Fig. 3a) from the colostrum-forming stage to that from a 7 month primagravida heifer were loaded onto the CM-Sepharose column, while only $6 \%$ of the total protein content of decaseinated mammary secretion during lactation (milk) was used.

stages. The presence of growth factor activity in mammary secretions from a nulligravida postpubertal heifer that was severalfold that detected in FCS at equal concentration ( $1 \%$, $\mathrm{v} / \mathrm{v}$ ) implied that a resident growth factor in mammary secretion before pregnancy could be involved in the limited pre- and postpubertal mammary development. All of the above suggest the involvement of growth factors, detected in mammary secretions, in regulating growth of the mammary gland during its transition from a nonlactating virgin gland to a lactating one. In fact, preliminary studies have shown that mammary secretions from a 7 month primagravida heifer stimulated $\left[{ }^{3} \mathrm{H}\right]$ thymidine incorporation in cultures of bovine mammary cells (Talhouk et al., 1988). In addition, bovine mammary cells in culture synthesized a heat stable, proteinasesensitive, growth-promoting activity that was modulated by the extracellular matrix (R. Talhouk, unpublished).
We have identified a 30000 molecular weight EGF-like bMDGF-1 growth promoting activity. While maximal EGF stimulation reached a plateau at about 80000 c.p.m., [3] H]thymidine incorporation induced by bMDGF-I attained 300000 c.p.m. In addition, bMDGF- 1 competed with ${ }^{125} \mathrm{I}-$ labelled mEGF for binding to AKR-2B cells in a dosedependent manner at both $4^{\circ} \mathrm{C}$ and $37^{\circ} \mathrm{C}$. This showed that the displacement was a direct binding of bMDGF- 1 to the EGF receptor and not a result of receptor 'transmodulation' (receptor-cross-talk: Sporn and Roberts, 1988).

The growth factors described in the literature within similar ranges of molecular weight and that could be involved in mammary gland development are HMGF-II (32 000-40 000 molecular weight) (Shing and Klagsbrun, 1984), PDGF-like CBGF (Brown et al, 1983; Brown and Blakeley, 1983b), and neu differentiation factor (NDF) (Yarden and Peles, 1991; Wen 
et al., 1992). HMGF-Il was described by the authors as a non-EGF-like activity, and hence different from bMDGF-1 (EGF-like). However, PDGF-like CBGF, detected in goat colostrum (Brown and Blakeley, 1983b), transmodulated EGFreceptor on 3 T3 cells. Thus, bMDGF-1 appears to be different from the 30000 molecular weight PDGF-like CBGF. This discrepancy in results could be attributed to the use of different cell lines in the mEGF competition binding assays, namely $3 \mathrm{~T} 3$ cells and AKR-2B cells.

Neu differentiation factor, a $44 \mathrm{kDa}$ molecule, chromatographically behaves as a $30-35 \mathrm{kDa}$ molecule and is similar to bMDGF-I in certain aspects. It is a heat stable glycoprotein, containing an EGF-like functional domain (Wen et al., 1992; Tzahar et al., 1994). Furthermore, it is a potent modulator of mammary development and function. It has been reported that NDF induced lobulo-alveolar development in mouse organ culture (Yang et al., 1995) and differentiation of mammary tumour cells (Peles et al., 1992). However, and in contrast to bMDGF-1, NDF does not bind to EGF receptor (erbB-1), but rather to erbB-4 and erbB-3 (Tzahar et al., 1994). It was suggested that the NDF receptor might heterodimerize with erbB proteins and hence induce their transactivation (Carraway and Cantley, 1994; Tzahar et al., 1994). Whether bMDGF-1 is different from NDF as described by Yarden and Peles (1991) and Yang ef al. (1995) or PDGF-like growth factor as described by Brown and Blakeley (1983b) requires further investigation.

The above observations suggest that either: (1) bMDGF-1 is a novel EGF-like factor capable of stimulating greater amounts of $\left[{ }^{3} \mathrm{H}\right]$ thymidine incorporation than does EGF, or (2) an EGF-like factor that competes for EGF binding on AKR-2B cells co-eluted with bMDGF-1, and that both factors interact to produce a synergistic effect. The latter is unlikely, since further column fractionation of the material used in the EGF-binding assay yielded a single peak of growthpromoting activity.

The other growth-promoting activity, bMDGF-2, is possibly IGF-I or IGF-II bound to IGF-binding proteins (IGFBP). Insulinlike growth factors (approximately 8000 molecular weight), circulate in the plasma bound to IGFBP with molecular weights of approximately 50000 and 150000 (Froesch et al.. 1985; McGuire et al., 1992). Francis et al. (1988) and Campbell and Baumrucker (1989) demonstrated an IGF-like activity with an apparent molecular weight of 50000 in bovine milk and colostrum. The pattern of elution of growth-promoting activities that we described for colostrum and milk are not different in profile but rather in ability to stimulate $\left[{ }^{3} \mathrm{H}\right]$ thymidine incorporation from those described for secretions from 7 month pregnant mammary secretions. This, in addition to the fact that few, if any, described growth factors are of a 50000 or 150000 molecular weight suggests that the high molecular weight forms of bMDGF-2 could be IGF bound to its IGFBP. It should be possible to test such observations with ELISA or other immunorelated techniques using antibodies to IGFs. Future studies will address this question.

Brown and Blakeley (1983b) reported a minor growth factor activity in colostrum of goats (different from colostrum basic growth factor) which did not compete with ${ }^{125}$ I-labelled mEGF binding to its receptors. Our competition curves showed only a $60 \%$ displacement of ${ }^{125}$ I-labelled mEGF by the decaseinated secretion from a 7 month primagravida heifer. This displacement was not affected when only bMDGF-1 was assayed for its ability to compete with ${ }^{125}$ I-labelled mEGF binding. This suggests that the other growth-promoting activity (bMDGF-2), found in the decaseinated mammary secretions but not in the partially purified preparations of bMDGF-1, does not contribute to ${ }^{125}$ I-labelled mEGF displacement. Thus, it is possible that the minor growth factor activity described by Brown and Blakeley (1983a) is bMDGF-2. Another growth factor with characteristics similar to bMDGF-2 was described by Bano et al. (1985). MDGFI, a 62000 molecular weight growth factor under denaturing conditions, was isolated from human milk. It did not compete with mEGF and was sensitive to protease treatment. At present, no other data are available to us that would allow determination of the identity of bMDGF-2.

In analysis of growth stimulatory activity in mammary secretions, two observations imply the presence of growth inhibitory activities: first, the decrease in $\left[{ }^{3} \mathrm{H}\right]$ thymidine incorporation observed in decaseinated mammary secretions from a 7 month primagravida heifer at concentrations of more than $0.5-1.5 \%(\mathrm{v} / \mathrm{v})$ in the assay; second, partial separation of the different entities in colostrum led to greater amounts of $\left[{ }^{3} \mathrm{H}\right]$ thymidine incorporation (150000 c.p.m.) than that achieved by colostrum (about 50000 c.p.m.). Bohmer et al. (1984) purified a $12-14 \mathrm{kDa}$ protein from lactating bovine mammary gland that inhibited the growth of Ehrlich ascites mammary carcinoma cells. The same group of investigators reported a TGF activity in acid-ethanol extracts of lactating bovine mammary gland, and in Ehrlich ascites mammary carcinoma cells (Eckert et al., 1985). This activity co-eluted with an activity that competed for the EGF receptor. Therefore, it is possible that TGF and the growth inhibitor (Bohmer et al., 1984) coexisted in the mammary gland, and possibly modulated the growth and development of the gland in an autocrine fashion. Knubbe et al. (1987) showed that TGF- $\beta$ produced by MCF7 cells acted as a negative growth regulator for human breast cell lines. Whether either of the growth-promoting activities we have shown act as positive or negative growth regulators on $\mathrm{AKR}-2 \mathrm{~B}$ cells and thereby account for the inhibition was not determined.

In conclusion, we have shown that mammary secretions from a nulligravida and a primagravida heifer contained growth-promoting activities that were modulated according to the stage of gestation. The growth factor activity reached a peak during the seventh month of gestation and declined after that through the colostrum-forming stage and into lactation. There are at least two growth factors in the mammary secretions at the seventh month of gestation: bMDGF-1 and an EGF-like polypeptide with a molecular weight of 30000 , and bMDGF-2 with an apparent molecular weight of 50000 or 150000 . The growth factor activities are modulated during development of the gland. Whereas bMDGF-1 is the major growth factor in pregnant and colostric secretions contributing to $\left[{ }^{3} \mathrm{H}\right]$ thymidine incorporation in AKR-2B cells, bMDGF-2 is the predominant growth factor in milk.

The authors are grateful to G. Wickramitalake for his excellent technical assistance and for R. Tawk for her assistance in the graphs. The authors also extend their thanks to R. Schwarz and C. Tarraf for 
critical reading of the manuscript. This research was supported in part by state and federal funds to the Ohio Agricultural Research and Development Center, Manuscript No. 10-96.

\section{References}

Bano M, Salomon DS and Kidwell WR (1985) Purification of a mammary-derived growth factor from human milk and human mammary tumours Journal of Biological Chemistry $2605745-5752$

Baumrucker CR and Blum JW (1994) Effects of dietary recombinant human insulin-like growth factor-I on concentrations of hormones and growth factors in blood of newborn calves Journal of Endocrinology 140 15-21

Baxter RC, Zaltsman Z and Turtle JR (1984) Immunoreactive somatomedin-C/ insulin-like growth factor- $I$ and its binding protein in human milk Journal of Clinical Endocrinology and Metabolism 58 955-959

Beardmore JM and Richards RC (1983) Concentration of epidermal growth factor in mouse milk throughout lactation Journal of Endocrinology 96 287-292

Bohmer FD, Lehmann W, Schmidt EH, Langen P and Grosse R (1984) Purification of a growth inhibitor for Ehrlich Ascites mammary carcinoma cells from bovine mammary gland Experimental Cell Research 150 466-476

Brem G, Hartl P, Besenfelder U, Wolf E, Zinovier N and Pfaller R (1994) Expression of synthetic cDNA sequences encoding human insulin-like growth factor-I (IGF-I) in the mammary gland of transgenic rabbits Gene $\mathbf{1 4 9}$ $351-355$

Brown KD and Blakeley DM (1983a) Cell growth promoting activity in mammary secretions of the goat, cow, and sheep British Veterinary Journal $13968-78$

Brown KD and Blakeley DM (1983b) Inhibition of the binding of the ${ }^{125} \mathrm{I}-$ labelled-EGF to mouse cells by a mitogen in goat mammary secretions Biochemical joumal 212 465-472

Brown KD and Blakeley DM (1984) Partial purification and characterization of a growth factor present in goat's colostrum. Similarities with platelet derived growth factor Biochemical Journal 219 609-617

Brown KD, Blakeley DM and Macdonald M (1983) Inhibition of EGF binding to Swiss $3 \mathrm{~T} 3$ cells by human platelet release products Bioscience Reports 3 659-666

Byyny RL, Orth DN, Cohen S and Doynes ES (1974) Epidermal growth factor: effects of androgens and adrenergic agents Endocrinology 95 776-782

Campbell PG and Baumrucker CR (1989) Insulin-like growth factor-I and its association with binding proteins in bovine milk Journal of Endocrinology 120 21-29

Carpenter G (1980) Epidermal growth factor with a major growth-promoting agent in human milk Science 210 198-199

Carpenter G, Lemback KJ, Morrison MM and Cohen S (1975) Characterization of the binding of ${ }^{125}$ I-labelled epidermal growth factor to human fibroblasts Journal of Biological Chemistry 250 4297-4304

Carraway KL and Cantley LC (1994) A neu acquaintance for erbB3 and erbB4: a role for receptor heterodimerization in growth signalling Cell 78 5-8

Cowie AT (1971) Influence of hormones on mammary growth and milk secretion. In Lactation pp 123-140 Ed. IR Falconer. Pennsylvania State University

Dembinski TC and Shiu RPC (1987) Growth factors in mammary gland development and function. In The Mammary Gland: Development, Regulation and Function pp 355-373 Eds MC Neville and CW Daniel. Plenum Publishing Corp., New York, London

Eckert K, Lubbe L, Schon R and Grosse R (1985) Demonstration of transforming growth factor activity in mammary epithelial tissues Biochemistry International 11 441-445

Eriksson U, Duc G, Froesch ER and Zapf J (1993) Insulin-like growth factors (IGF) I and II and IGF binding proteins (IGFBPs) in human colostrum/ transitory milk during the first week post-partum: comparison with neonatal and maternal serum Biochemical and Biophysical Research Communications 196 $267-273$

Fenton SE and Sheffield LG (1991) Lactogenic hormones increase epidermal growth factor messenger RNA content of mouse mammary glands Biochemical and Biophysical Research Communications 181 1063-1069

Forsyth IA (1991) The mammary gland Baillieres Clinical Endocrinology and Metabolism 5 809-832

Francis JL, Read LC, Ballard FJ, Bagley CJ, Upton M, Gravestock PM and Wallace JC (1986) Purification and partial sequence analysis of insulin-like growth factor-1 from bovine colostrum Biochemical Journal 233 207-213
Francis JL, Upton FM, Ballard F), McNeil KA and Wallace JC (1988) Insulin-like growth factors 1 and 2 in bovine colostrum: sequences and biological activities compared with those of a potent truncated form Biochemical journal $25195-103$

Froesch ER, Schmid CHR, Schwander J and Zapf J (1985) Actions of insulin-like growth factors Annual Review of Physiology 47 443-467

Kidwell WR and Salomon DS (1987) Origin of growth factors in human milk Federation Proceedings 46570 (Abstract)

Klagsbrun M (1978) Human milk stimulates DNA synthesis and cellular proliferation in cultured fibroblasts Cell Biology 75 5057-5061

Klagsbrun M and Neumann J (1979) The serum free growth of Balb/c 3T3 cells in medium supplemented with bovine colostrum Journal of Supramolecular Structure $11349-359$

Knubbe C, Lippman ME, Wakefield LM, Flanders KC, Kasid A, Derynck R and Dickson RB (1987) Evidence that transforming growth factor- $\beta$ is a hormonally regulated negative growth factor in human breast cancer cells $\mathrm{Cell} \mathbf{4 8}$ 417-418

McGuire MA, Vicini JL; Bauman DE and Veenhuizen JJ (1992) Insulin-like growth factors and binding proteins in ruminants and their nutritional regulation Journal of Animal Science 70 2901-2910

Marcotty C, Franken F, Meuris S and Hennen G (1994) Immunolocalization and expression of insulin-like growth factor I (IGF-I) in the mammary gland during rat gestation and lactation Molecular and Cellular Endocrinology 99 $237-243$

Oka T, Yoshimura M, Lavandero S, Wada K and Oba Y (1991) Control of growth and differentiation of the mammary gland by growth factors Journal of Duiry Science 74 2788-2800

Peles E, Bacus SS, Koski RA, Lu HS, Wen D, Ogden SG, Ben Levy R and Yarden Y (1992) Isolation of the neu/HER-2 stimulatory ligand: a 44 kd glycoprotein that induces differentiation of mammary tumor cells Cell 69 205-215

Plaut K (1993) Role of epidermal growth factor and transforming growth factors in mammary development and lactation Journal of Dairy Science $\mathbf{7 6}$ 1526-1538

Pollard JW and Henninghausen L (1994) Colony stimulating factor 1 is required for mammary gland development during pregnancy Proceedings of the National Academy of Sciences USA 91 9312-9316

Read LC, Upton FM, Francis GL, Wallace JC, Dahlenberg GW and Ballard FJ (1984) Changes in the growth promoting activity of human milk during lactation Pediatric Research 18 133-139

Schober DA, Simmen FA, Hadsell DL and Baumrucker CR (1990) Perinatal expression of type I IGF receptors in porcine small intestine Endocrinology $126 \quad 1125-1132$

Sereni A and Baserga R (1981) Routine growth of cell lines in medium supplemented with milk instead of serum Cell Biology International Reports $\mathbf{5}$ 339-345

Shing YW and Klagsbrun M (1984) Isolation of growth factors from human milk. In Methods for Preparation of Media, Supplements and Substrata for Serum-free Animal Cell Culture pp 159-179. Alan R. Liss Inc., New York

Simmen RC, Ko Y, Liu XH, Wilde MH, Pope WF and Simmen FA (1988) Autocrine cell mitogen distinct from epidermal growth factor in porcine uterine luminal fluids: characterization and partial purification Biology of Reproduction 38 551-561

Skaar TC, Vega JR, Pyke SN and Baumrucker CR (1991) Changes in insulin-like growth factor-binding proteins in bovine mammary secretions associated with pregnancy and parturition Journal of Endocrinology 131 127-133

Smith KL and Schanbacher FL (1973) Hormone induced lactation in the bovine. I. Lactational performance following injections of $17-\beta$-estradiol and progesterone Journal of Dairy Science 56 738-743

Soriano JV, Pepper MS, Nakamura T, Orci L and Montesano R (1995) Hepatocyte growth factor stimulates extensive development of branching duct-like structures by cloned mammary gland epithelial cells Journal of Cell Science 108 413-430

Spitzer E and Grosse R (1987) EGF receptors on plasma membranes purified from bovine mammary gland of lactating and pregnant animals Biochemistry International $14581-588$

Spitzer E, Zfchiesche W, Binaf B, Grosse R and Erdmann B (1995) EGF and IGF- $\alpha$ modulate structural and functional differentiation of the mammary gland from pregnant mice in vitro: possible role of the arachidonic acid pathway Journal of Cellular Biochemistry 57 495-503

Sporn MB and Roberts AB (1988) Peptide growth factors are multifunctional Nature $332 \quad 217-219$ 
Talhouk R, Palin L, WicKramatilake and Schanbacher FL (1988) Growth factor activity in secretions from developing bovine mammary gland Journal of Cell Biology $107269 a$

Talhouk R, Neiswander RL and Schanbacker FL (1990) In vitro culture of cryopreserved bovine mammary cells on collagen gels: synthesis and secretion of casein and lactoferrin Tissue and Cell $22 \quad 583-599$

Tokuyama Y and Tokuyama $\mathbf{H}$ (1993) Purification and identification of TGF- $\beta 2$ related growth factor from bovine colostrum Journal of Dairy Research 60 99-109

Tzahar E, Levkowitz G, Karunagaran D, Yi L, Peles E, Lavi S, Chang D, Liu N, Yayon A, Wen D and Yarden Y (1994) ErbB-3 and erbB-4 function as the respective low and high affinity receptors of all neu differentiation factor/ heregulin isoforms Journal of Biological Chemistry $26925226-25233$
Wen D, Peles E, Cupples R, Suggs SV, Bacus SS, Luo Y, Trail G, Hu S, Silbiger SM, Ben Levy R, Koski RA, Lu HS and Yarden Y (1992) Neu differentiation factor: a transmembrane glycoprotein containing an EGF domain and an immunoglobulin homology unit Cell 69 559-572

Winder SJ, Wheatley SD and Forsyth IA (1993) Receptor binding of insulin-like growth factor-I to mammary microsomes from non-pregnant and lactating sheep Journal of Endocrinology 136 297-304

Yang Y, Spitzer E, Meyer D, Sachs M, Niemann C, Hartmann G, Weidner KM, Birchmeier and Birchmeier W (1995) Sequential requirement of hepatocyte growth factor and neuregulin in the morphogenesis and differentiation of the mammary gland journal of Cell Biology 131 215-226

Yarden Y and Peles E (1991) Biochemical analysis of the ligand for the neu oncogenic receptor Biochemistry 30 3543-3550 